\title{
"Waiting for the Sages of Later Generations": Is there a Rhetoric of Treason in the Shiji?
}

"En attendant les Sages à venir... ": à propos d'une rhétorique de la trahison dans les Mémoires historiques (Shiji) de Sima Qian “俟世聖人君子”：試論《史記》中的影射性修辭

Dorothee Schaab-Hanke

\section{OpenEdition}

\section{Journals}

\section{Electronic version}

URL: https://journals.openedition.org/extremeorient/256

DOI: 10.4000/extremeorient.256

ISSN: 2108-7105

\section{Publisher}

Presses universitaires de Vincennes

\section{Printed version}

Date of publication: 1 November 2012

Number of pages: 111-140

ISBN: 978-2-84292-352-5

ISSN: 0754-5010

\section{Electronic reference}

Dorothee Schaab-Hanke, "'Waiting for the Sages of Later Generations": Is there a Rhetoric of Treason in the Shiji?", Extrême-Orient Extrême-Occident [Online], 34 | 2012, Online since 01 November 2015, connection on 21 September 2021. URL: http://journals.openedition.org/extremeorient/256 ; DOI: https://doi.org/10.4000/extremeorient.256 


\title{
"Waiting for the Sages of Later Generations": Is there a Rhetoric of Treason in the Shiji?
}

\author{
Dorothee Schaab-Hanke
}

\section{Introduction}

While allusions per se are, of course, legion in the text of the Shiji ("The Scribe's Record"), a comprehensive historiographical work finalized around 86 $\mathrm{BCE},{ }^{1}$ the case example to be adduced here seems to be of particular interest in the context of the focus on "rhetoric as a political tool." As will be argued, the use of this allusion reveals much about the attitude of the Shiji's two authors, or at least of one of them, towards Emperor Wu (r. 141-87), the emperor under which Sima Tan (?-110) and his son, Sima Qian ( $c a$ 145-ca 86), ${ }^{2}$ served successively in the position of "Director the Grand Scribe" (taishi ling). ${ }^{3}$

All five passages where that allusion occurs have in common that they refer to one specific passage of the Gongyang zhuan, one of the three earliest transmitted texts commenting or, to put it more precisely, interpreting the "Spring and Autumn" Annals (Chunqiu), a terse chronicle of the state of Lu, spanning

1. All dates are BCE unless indicated otherwise. For the revised version of my paper, I am much indebted to the members of the editing team and the most helpful suggestions by Yuri Pines, Joachim Gentz, Michael Nylan, Steve Durrant, and two anonymous reviewers.

2. In spite of the suggested dual authorship of the Shiji I will, until the last section of this essay, merely speak of "the author" or "the historiographer," assuming that it is always the voice of one of them which is speaking to us at a time. In the last section, however, it will be argued that in the examples adduced here the voice of either Sima Tan 司馬 談 or Sima Qian 司馬遷 may be distinguished quite clearly.

3. Since the duties of a taishi ling 太史令 covered the realm of astronomy as well as that of astrology, it is not easy to translate satisfactorily. Michael Nylan (1998-1999: 203) proposes to render taishi 太史 as “senior archivist," but since an archivist's role seems to be merely one aspect of the many duties of a taishi I prefer to stick to the more general term "Grand Scribe." 
the years from 722 to 481, the so-called Spring and Autumn Period. ${ }^{4}$ In that passage Confucius is reported to have lost hope that a sage ruler might appear during his own lifetime, shortly after a unicorn had been caught. As a reaction to this, he decided to devote his work, the Chunqiu, in which the moral rules governing the relations between the states of that period are laid down, to sages and superior men of later generations. ${ }^{5}$ Very similarly, the Shiji author in those five passages of his text addresses the sages and superior men of later generations, expressing his hope that they might make use of the work he had compiled and left for posterity. ${ }^{6}$

As I will argue, each of the five passages in which the historiographer thus alludes to the Gongyang zhuan adds one facet to an overall critical assessment of Emperor Wu (r. 141-87). ${ }^{7}$ And what is more, it will be argued that the temporal aspect characteristic of both the Gongyang zhuan prototype and the historiographer's allusion to it implies that the critical attitude displayed was in both cases not merely a warning, but rather a final condemnation-small wonder that someone who expressed such criticism easily incurred the risk of being charged with having committed lèse majesté, in other words, high treason. ${ }^{8}$

4. Hereafter, references to the Gongyang zhuan 公羊傳, as well as to the Guliang zhuan 穀梁傳 and Zuozhuan 左傳, will be made as to the ICS edition.

5. To my knowledge, there are few studies so far that have examined the impact of the Gongyang zhuan on the Shiji author in detail. Among Chinese Shiji specialists, attention on the Shiji as an exegetical work has increased within the last decade, the perhaps most pioneering being that of Chen Tongsheng (1995), who painstakingly traced the impact of all three exegetical commentaries of the Chunqiu on the Shiji.Among Western studies, Jurij L. Kroll (1976), in an essay on the Shiji as a literary work, has already pointed out that the Gongyang tradition was of major importance for the judgements passed by the author of the Shiji.

6. It is important to add that all five passages in which this allusion occurs are part of the historiographer's personal remarks, which are usually introduced by the formula "His Lord the Grand Scribe says" (taishigong yue).

7. Although the focus of this study is on the relations between the Shiji and the Gongyang zhuan, this is, of course, in no way meant to belittle the impact that the Zuozhuan had on large parts of the Shiji. For an insightful study of Shiji chap. 14 in which the table entries are interpreted as often being a synopsis of positions taken by the Zuozhuan, see Durrant (1992); see also Hardy (1993). For a discussion of the various exegetical positions taken by the Shiji author in the context of the comments introduced by "A superior man said" (junzi yue 君子曰), see Schaab-Hanke (2010a).

8. The choice of the term "rhetoric of treason" for the allusion under discussion here was inspired by the intriguing essay by Gary Arbuckle (1995) in which he illustrates how, by applying doctrines of the Gongyang school on the politics of his time, the Han scholar Dong Zhongshu, as well as scholars in his succession, was almost inevitably charged with high treason. 
In a first step, the relevant passage of the Gongyang zhuan will be examined and compared with the five related passages in the Shiji text; then, the historiographer's personal remarks containing the allusions to the Gongyang zhuan will be analyzed within the context of the given chapters; the third step will be to illustrate how the allusion to the Gongyang zhuan is used here as a tool to pass a final judgment on Emperor Wu rather than to simply warn him; closely related to this is the fourth step, in which the question of Emperor Wu's sagacity is discussed in the Shiji; and, last but not least, the question of "the historiographer's" identity will be raised.

\section{The relevant passage in the Gongyang zhuan and the five related passages in the Shiji}

The passage in the Gongyang zhuan which is the focus of our interest here appears in the very last section of the transmitted text. Commenting on the Chunqiu entry related to the 14th year of Duke Ai of the state of Lu (481) which records that a unicorn had been caught during a hunt somewhere to the west of the Lu capital, Qufu, the author of the Gongyang zhuan asks why this record was made in the Chunqiu. Upon hearing of the capture of the unicorn, Confucius reportedly "rolled up his sleeves and wiped off his tears" and lamented that his way had come to an end. Then, the author of the Gongyang zhuan reflects on the question why the "superior man" (Confucius) compiled the Chunqiu. Was it because he was of the opinion that in a world full of chaos and decline, there was no better way to manage the crisis than by applying the rules of the Chunqiu? Or was it simply because the Master himself took delight in the way in which Yao recognized Shun? ${ }^{9}$ While in his interpretation the author of the Gongyang zhuan seems to hesitate about what may have been the primary motivating force for Confucius to compile the Chunqiu, in his final statement he turns his attention away from the age in which Confucius lived toward a point in time somewhere in the future when sages and superior men would live and to whom Confucius addressed his work on "Spring and Autumn" (zhi Chunqiu). The book ends with the words:

Indeed, he (=Confucius) applied the moral rules of the "Spring and Autumn (Annals)" to wait for sages of later (generations); it was for superior men that (this work) was made, and this is also something that he took delight in. ${ }^{10}$

9. Many thanks to Yuri Pines who alerted me that this passage refers to the idea of Yao's abdicating in favor of Shun (communication of 15.02.12).

10. Gongyang zhuan 12.14.1 (158/13-15): 制春秋之義, 以俟後聖。以君子之為, 亦有 樂乎此也。 $C f$. Gentz 2001: 89-92. 
Apart from the Gongyang zhuan, both the Zuozhuan and the Guliang zhuan also comment on this event. While the Zuozhuan mentions the incident only briefly, explaining that the driver of a carriage had discovered the animal and, fearing it could be inauspicious, brought it to Confucius who identified it as a unicorn, the Guliang zhuan interprets it as an auspicious animal. The author of the Gongyang zhuan not only devotes the most attention to the capture of the unicorn, but he is also the only one to reflect upon the relation between the appearance of the unicorn and its possible impact on Confucius and his work. ${ }^{11}$

Let us now take a first look at the five passages in the Shiji that contain allusions to the above mentioned passage in the Gongyang zhuan and the way they are formulated. Listed according to the sequence of chapters in the Shiji these passages appear in chapters $12,15,18,28$ and 130 of the transmitted text. Each of these passages is part of the section introduced by the formula "His Lord the Grand Scribe says" (taishigong yue), the historiographer's personal remarks, usually found at the end, but at times also at the beginning of a chapter. ${ }^{12}$

In two of these five passages, the allusion is formulated as follows: "If there will be superior men later on, they may make use of it for their examination." 13 This formula is only slightly varied in two further passages: "If there will be superior men later on, they may make use of this for their examination and peruse," and: "If there will be superior men later on who want to add their own discussions accordingly, they may make use of this (material) for their examination." ${ }^{14}$ The fifth passage contains the allusion that from its very wording comes closest to Confucius' statement as it is recorded in the Gongyang zhuan. It is there that the historiographer says that the "Book of His Lord, the Grand Scribe" (taishigong shu) should "wait for the sages and superior men of later generations." 15

\section{Closer analysis of the five Shiji passages in their context}

After having examined the context of the Gongyang zhuan passage and having compared the wording of that passage with the related passages in the

11. For the comments on Aigong 14.1 made in Zuozhuan, see B12.14.1/456/21-22; for those in Guliang zhuan, see 12.14.1/154/3-4. See also the comparison made by Gentz 2001: $288 f$.

12. For a closer study of the authority represented by the formula taishigong yue 太史公 曰, see Li Wai-yee 1994.

13. Shiji 12.486 and 28.1404: 後有君子, 得以覽焉。

14. Shiji 15.687, 4: 後有君子, 以覽觀焉。Shiji 18.878, 10: 後有君子, 欲推而列之, 得以覽焉。

15. Shiji 130.3319: 15-3320: 1: 為太史公書，〔 .. ) , 俟後世聖人君子。 
Shiji, a closer look will be taken at the overall context of each of these five Shiji passages, following the order in which these passages occur in that work.

\subsection{Tracing the "first signs of transgression" in the early state of Qin}

Shiji 15, the "Table by Years of the Six States," can be roughly summarized as treating the historical events between the year 475 and the year 207, from the time when the state of Qin was founded, until the final downfall of the shortlived Qin dynasty, in all 270 years. ${ }^{16}$

In the table, we have strictly speaking eight partners listed in the grid, beginning with Zhou in the upper horizontal row, followed by Qin in the second row, and Wei, Han, Zhao, Chu, Yan, and Qi in the next rows; however, as the title "Six States" already indicates, both Zhou and Qin are not reckoned among the others, since Zhou was the-increasingly weak-center, while Qin was the newcomer, whose development in relation to the other states of that period is spotlighted in this chapter.

In some respects, the content of the table is a synopsis of chapters 5 and 6 of the Shiji. In the annals section the history of Qin is bipartite, the first part tracing the history of the state of Qin in its interactions with the other regional states and the second part dealing with Qin after its unification of the empire until the downfall of the Qin dynasty. The table in chapter 15, however, shows all the important information on the political history of these times in chronological order. The table thus perfectly mirrors how the center of power shifted in the course of these years: The weakening of Zhou is indicated by the fact that after the year in which Zhou King Nan died (indicated by the Zhonghua editors as the year 256) there are no more entries in the upper row, ${ }^{17}$ and from the year 246 on, the year in which Prince Zheng, King of Qin, came to the throne, there is no row reserved for Zhou. Instead, Qin has taken its place. ${ }^{18}$ From 220 on, the table changes even more radically. There are no more horizontal rows from this point on, but only one vertical table which comprises all major events relating to the united empire of Qin. ${ }^{19}$

The content of the historiographer's personal remarks right at the beginning of the chapter can be roughly summarized as giving a brief survey of the route taken by the state of Qin from its first appearance as a "small and remote" state toward a powerful state which, after having swallowed up one state after the

16. Shiji 15.685-758 (“Liuguo nianbiao”六國年表).

17. See Shiji 15.748: 2.

18. See Shiji 15.751: 3 .

19. See Shiji 15.757: 7. 
other, finally succeeded in establishing its rule over the whole empire. ${ }^{20}$ While basing his account primarily on the records of the state of Qin itself, the Shiji author laments that he was forced to do so because the Qin had destroyed the annals of all the other states. ${ }^{21}$

His account deals with how the state of Qin first appeared in history, traces the development of this state, and describes how Qin eventually swallowed up one state after the other, until by 221 , after unifying the empire under one central rule, the Qin were able to announce their own dynasty, which he continues to outline through the short period of this empire until its fall in 207. This is how the historiographer's personal remarks end:

Thus, basing myself on the records of Qin, following in the footsteps of the Chunqiu, beginning with King Yuan of Zhou, I have made a table of the events in the time of the Six States, comprising altogether 270 years; and I have written down all that I have heard concerning the first signs of prosperity and decay. ${ }^{22}$ If there will be superior men in future generations, they may make use of this (material) for their examination and research..$^{23}$

The historiographer's personal attitude towards the Qin state's rise to power in this chapter is rather ambiguous. On the one hand he seems to have been quite impressed by the way the Qin managed to change with the times and thus find strategies not only for survival but for becoming the fittest of the Warring States period. While he does not seem convinced that the Qin had special advantages

20. Zhang Dake 2000: 405, has counted altogether 196 armed conflicts between states in the time before the unification of the empire by the Qin.

21. Yuri Pines (2005/2006) certainly justly reproaches the Shiji for being a biased source in many respects. However, in my view, this is an example where the historiographer explicitly points out that the annals of Qin were his only major source, which he bemoans, and on the other hand the tables themselves show that the historiographer had devoted great energy to recording the events of each of the states of the Warring States period separately, in spite of or even against the grain of this certainly highly biased source, so that I think the historiographer in cases such as this deserves some respect.

22. The term duan 端, “beginning," or, as rendered here, "first signs," occurs conspicuously often in the Chunqiu fanlu 春秋繁露 (Luxuriant Dew of the Spring and Autumn [Annals]), a text ascribed to Dong Zhongshu who received an official chair under Emperor Wu. See, e.g., the phrase “cun wang zhi duan bu ke bu zhi ye" 存亡之端不可不知也 (“It is of utmost importance that one understands the first signs of [what brings about] continuity or perdition!") in a section entitled “Mie guo" 滅國 (Destroying a state). See Chunqiu fanlu (ICS ed.) 5.1/19/13. I owe this hint to the importance of that term for the Han interpretation of the Gongyang school to Joachim Gentz, communication of 07.07.2011.

23. Shiji 15.687,3-4: 余於是因秦記, 踵春秋之後, 起周元王, 表六國時事, 訖二世, 凡二百七十年，著諸所聞興壞之端。後有君子，以覽觀焉。Cf. Chavannes 1898: 22-28; Watson 1958: 184ff. 
- be they strategic or geographic, he assumes that Qin must have been favored with Heaven's blessing. On the other hand, in the author's account throughout this chapter there is a critical undertone, namely that the Qin always tended towards violence and usurpation, so that a "superior man would be frightened." ${ }^{4}$ Thus, in my opinion, the historiographer's overall attitude towards the Qin is rather a critical one.

Right from the beginning, the Shiji author attributes to them a certain trait of arrogance in usurping privileges which would have been the prerogative of the Son of Heaven, then still represented by the Zhou. The Qin conducted sacrifices, which were not appropriate to their status, and by conceding these to the Qin, the Zhou's increasing weakness became more and more apparent. This is what the historiographer denotes as the "first signs of transgression" which thus became noticeable. ${ }^{25}$ Very similarly, by referring to "first signs of prosperity and decay" (xing shuai zhi duan), the historiographer, not without a critical undertone, describes how the early Qin rulers had first achieved their unexpectedly rapid success in unifying the empire and how the rulers of the unified empire then, even more quickly, brought about their own ruin.

There is thus little doubt that the Shiji author takes the development of Qin, which was initially successful but soon doomed to fail, as the historical lesson which his readers - superior men of later ages - should learn and apply in later generations to their own circumstances. And the question to be raised here is whether the historiographer indirectly accuses the emperor of his own time, Emperor $\mathrm{Wu}$, of showing similar traits of arrogance and violence in expanding his empire and assuring his recognition as the ruler of "All under Heaven." ${ }^{26}$

\subsection{Criticizing Emperor Wu for his abolishment of so many fiefs}

The content of Shiji 18, "Table by Years of Marquisates Conferred on Meritorious Followers of Gaozu," ${ }^{27}$ is more easily understood if one takes a glimpse at the content of the preceding chapter and of the two following it. While chap. 17 is devoted to all nobles (hou) who had been made kings since

24. Junzi ju yan 君子懼焉, see Shiji 15.685: 8.

25. Qianduan xian yi 櫭端見矣, see Shiji 15.685: 7. In rendering the term qian 僭 with "transgression" I follow the translation proposed by Yuri Pines 2005/2006: 12.

26. For an earlier study on the-conspicuously quite similar-portrayals of Emperor Wu of the Han and the First Qin Emperor, especially as regards their desire to attain immortality, see Durrant 1994. In a forthcoming essay, Hans van Ess also points to the close resemblance of the pictures of both emperors as they were drawn by the Shiji author. I am obliged to Yuri Pines for directing my attention to the latter essay.

27. Shiji 18.877-975 (“Gaozu gongchen houzhe nianbiao” 高祖功臣侯者年表). 
the rise of the Han, chap. 19 concentrates on the creation of nobilities ${ }^{28}$ during the reigns of the Emperors Hui to Jing, (i.e., from 194 to 141), while chap. 20 is devoted to the nobilities newly created from the reign of Emperor Wu on (i.e., beginning with the year 140).

The horizontal axis of the table contained in chap. 18 lists the names of the areas that had been bestowed on these meritorious ministers during the reign of the dynasty founder Liu Bang, posthumously Gaozu. The columns on its vertical axis indicate the name of the first holder, the reason why he had been bestowed, followed by the reign years of all emperors down to Emperor Wu.

In his personal remarks, again found at the beginning of the chapter, the historiographer sets out to list five different types of merits for which officials were bestowed with marquisates in ancient times, and he emphasizes the overriding importance of the preservation of the fiefs over generations to their owners.

He then turns his attention to the more than one hundred of the dynasty founder's followers to whom Liu Bang bestowed fiefs in reward for their merits during the rise of the new dynasty. He describes how these domains grew both in power and wealth, in accordance with their population growth, and that over the generations the descendants of these marquises became more and more arrogant.

As a consequence, the historiographer continues, by the beginning of the era of Taichu [Grand Inception], only five of the descendants of these marquises were still able to preserve their fiefs. ${ }^{29}$ As for the rest, he continues, most of them were deprived of their fiefs because they had violated the law and thus lost their lives, and the nobilities were thus abolished. Certainly, the historiographer adds, the laws of the empire by this time had become somewhat stricter than earlier, but others say that they did not really strive to accommodate the restrictions of the times.

The historiographer concludes with the words:

Living in the present age, one's intentions should be directed to the ways of old, in order to have a mirror for oneself, but the ages are still not wholly comparable. The emperors and kings all differ as regards the moral rules (one has to apply) and vary as regards the duties (one has to fulfil); thus, making "merit" one's standard, how should one not intermingle these?

28. In my use of the term hou 侯, "nobility" with regard to the fiefs bestowed on meritorious officials, I follow the terminology proposed by Michael Loewe (2004) in a section focused on "The Nobilites of the Western Han." On p. 284, he writes, "Conferred by imperial decree, a nobility gave the recipient a title in the form of designating the area in which he was entitled and obliged to raise taxation and call up those of the inhabitants who were liable to render service, either in the armed forces or as conscript labourers."

29. Shiji 18.878: 2 . 
If one takes a look at the reasons that brought them honor and those that brought them shame, one will see that there is also a whole forest of merits and deficiencies in our present age-how would one have heard about them in former times!

Therefore, I have meticulously traced the matters from their beginnings to their ends, listed what has been recorded of them; as for those matters that could not thoroughly be traced, I noted down what was documented and left out what is up to doubt. If there will be superior men of later (generations) who want to add their own discussions accordingly, they may make use of this material for their examination. ${ }^{30}$

But what is the lesson that "superior men of later (generations)" should learn from this chapter? It seems that there are mainly two aspects: firstly, that during the reign of Emperor Wu, many of those fiefs that had been established under Gaozu were conspicuously abolished; and secondly, that during Emperor Wu's reign the rules regarding what was meritorious and what was not became so complicated that it was increasingly difficult for the marquises to preserve the domains that they had inherited from their ancestors. Both aspects will be examined by taking a closer look at the table itself.

Tracing the number of nobilities abolished during the reigns of the Han emperors as indicated in the table, one can indeed observe that the domains abolished under Emperor Wu by far exceed the closures during the reigns of the emperors preceding him. Of all the 143 nobilities bestowed by Emperor Gaozu on meritorious officials, only five had been abolished during his own reign, two further under the reign of Emperor Hui, nine during the reign of Empress Lü, twenty one under Emperor Wen, thirty-four under Emperor Jing, and seventy under Emperor Wu. Since all of the seventy nobilities abolished during the reign of Emperor Wu, sixty-five are recorded for the period between the beginning of his reign and the end of the Yuanfeng period (110-105), and only five further in the time from the beginning of the Taichu period until the end of his reign (104-87), the table data corroborate the historiographer's remark, made in his preface to the table, that by the beginning of the Taichu period, only five out of the more than one hundred nobilities were still preserved. ${ }^{31}$

As for what the historiographer calls "a whole forest of merits and deficiencies in our present age" 32 in his personal remarks, the table entries also provide the

30. Shiji 18.878, 8-10: 居今之世, 志古之道，所以自鏡也，未必盡同。帝王者各殊禮 而異務, 要以成功為統紀, 豈可緄乎? 觀所以得尊寵及所以廢辱, 亦當世得失 之林也, 何必舊聞? 於是謹其終始, 表其文, 頗有所不盡本末; 著其明, 疑者 關之。後有君子, 欲推而列之, 得以覽焉。Cf. Chavannes 1898: 125; $c f$. Watson 1961a: 427ff.

31. According to the table, the names of these five nobilities were Yanghe, Dai, Quzhou, Pingyang and Guling. See also the Zhengyi commentary by Zhang Shoujie, Shiji 18.878: 7 .

32. Dangshi de shi zhi lin 當世得失之林. See Shiji 15.878: 9. 
reader with the reasons why the meritorious men enfeoffed by Gaozu or their descendants had lost their domains.

The reasons indicated in the table can be roughly classified as falling into three categories: firstly, that the nobility holder had died without having a son or other successor to his family line; secondly, that the nobility holder in compensation for his nobility received another fief or title; and thirdly, that the holder of a nobility was deprived of his domain due to his being charged with some crime.

Among these three categories, the second - the nobility holder received other fief or title-is the smallest (only four cases among the 141 closures); as regards the first reason - the nobility holder died without a successor - there are also few cases (altogether twenty-six); very much in contrast, the third reason indicated in the table entries - nobility lost due to the nobility holder being charged with crime - prevails by far (111 cases). If one compares the numbers indicated for the reigns of Han rulers, it can be observed that the number of domains abolished during the reign of Emperor $\mathrm{Wu}$ due to the nobility holder being charged with a crime exceeds that of all previous Han rulers taken together, namely altogether sixty-four cases. ${ }^{33}$

Of all 111 cases in which the nobility holder was charged with a crime, in thirty three cases the historiographer did not specify the reason for the charge. In seventy-eight cases, however, the reason is specified. During the time of Emperor $\mathrm{Wu}$, of the sixty-four domains that were closed due to their holders being charged with a crime, no crime is specified for only eight of the sixtyfour cases where domains were closed due to their holders being charged with a crime, whereas in fifty-six cases they were specified. And here as well, there is a significant difference between the time before and after the beginning of the era of Taichu: of all fifty-six cases in which a charge for a specified crime was made, fifty-one can be dated before the beginning of the era of Taichu, i.e. before the year 104, and only five in the time after; and in none of the eight cases in which an unspecified charge was made was this later than 104.

The data shown in the table thus clearly translate what the historiographer must have meant by that "forest of merits and deficiencies." It is a metaphor for a situation in which the standards of what was right and wrong must have become so complicated or even arbitrary that almost none of the descendants of those men who had once received these domains for their merits proved deserving enough to preserve them under Emperor Wu.

33. The number given for Gaozu is 2, for Huidi 1, for Lühou 4, for Wendi 13, and for Jingdi 27 , in all 47. 
What is more, during the time from the beginning of Emperor Wu's reign until the end of the Yuanfeng period, i.e. the years between 140 and 105, there is one year in which a conspicuously large number of fiefs, namely seventeen out of altogether fifty-one closures, are recorded in the table as abolished, namely the year 112. Apart from two cases, all the others - in all fifteen persons - were charged with misbehavior in the context of the "Liquor Gold Statute." This statute, which had probably been introduced by Han Emperor Wen, stipulated that the nobles - who were exempt from taxes - were requested to assist at the celebration of the annual ceremony of Imperial liquor. The amount of gold to be delivered was to be proportionate to the size of the nobles'domains. ${ }^{34}$ Indeed in 112, an order was issued for an inspection of the gold that the nobles had presented to the throne. The result of this inspection was that in many cases the nobles had not presented adequate gold, either in quality or in quantity, as required by the size of their domains. Many nobles were thus deprived of their nobility in the very same year. ${ }^{35}$

Viewed in the light of the Shiji author's remarks, it seems that the many different reasons given for persons being deprived of their fiefs during Emperor Wu's reign, and especially those who lost their fiefs on the basis of the Imperial liquor ceremony, exemplify what the historiographer laments in his preface. $\mathrm{He}$ also seems to suggest that all these apparently unprecedented reasons were, in

34. The Liquor Gold Statute, zhoujin lï 酎金律, or, more precisely, the Statute "on the Gold (presented at the Sacrifice of the Eighth Month) Fermented Liquor" was, according to Hulsewé (1955), 38, a statute that contained the rules concerning the compulsory contributions to be made by the nobility. As Dubs (1944), 126, explains, "nobles were exempt from taxes, but they were required to make an offering proportionate to the size of their estates in order to assist in defraying the expenses of the sacrifices to the imperial ancestors at the time of the offering of the specially fermented liquor in the eighth calendar month. Failure to offer the required amount was punished by dismissal from noble rank or degradation."

35. According to the table entries in Shiji 18, in the year 112 the following nobilities among those that had been established by the dynasty founder Gaozu were closed because their owners were charged with irregularities related to their duties in the context of the Imperial liquor ceremony: Jiang, Liangzou, Xinyang, Zhifang, Aling, Chiqiu, Pinggao, Gao, Qing, Eshi, Luliang, Kaifeng, Linyuan, De, Tao. The only two owners of nobilities charged with other crimes were those of Zhi (charged with immoral behavior) and Lecheng (charged with murder and executed in public). The even much higher number of all 106 nobles who were deprived of their nobilities in 112 given by Loewe (2004: 294) must be based on the table entries of Hanshu 16 which also includes the nobilities newly established for merit under the Emperor Hui, Empress Lü, and Emperor Wen. 
the first place, merely a pretext for the emperor to abolish these fiefs.$^{36}$ Very similarly, Michael Loewe interpreted the reason why Emperor Wu abolished so many of the fiefs that the dynasty founder, Gaozu, once had created, saying,

It seems unlikely that this major change was due simply to the reasons that were alleged. Possibly the step was taken as a deliberate measure to eliminate the influence of some of the well-established families of the day. Possibly it may be construed as punishment for failure to respond to a call for volunteers to join the campaigns against rebels from Nan Yue or from among the Qiang peoples. ${ }^{37}$

It is certainly plausible to assume that Emperor Wu's major interest was to eliminate the influence of what Loewe calls "the well-established families of the day." But perhaps one should even consider a possible connection between the steps taken by this emperor towards elimination of more and more of these regional powers and his own steady progression towards a more centralized and bureaucratic state. Against this political background, a detail indicated in one of the table columns mentioned above seems to deserve special attention: Different from the reign years of all the other emperors, the historiographer has divided the entries in the column relating to Emperor $\mathrm{Wu}$, into two parts, the first part comprising the first 36 years (i.e. from the beginning of Jianyuan, 140 , to the end of Yuanfeng, 105), and the second part comprising the latter 28 years of his reign (i.e. from the First Year of Taichu, 104, to the Second Year of Houyuan, 87). ${ }^{38}$ Thus it even seems that the historiographer intended to turn his reader's attention to the fact that Emperor Wu abolished the largest numbers of fiefs before the year 104 .

Since the very name of the era Taichu - "Grand Inception"-is closely linked with the installation of a grand new calendar, to be inaugurated soon after Emperor Wu had successfully conducted the Feng and Shan Sacrifices on Mount Tai, it does not seem too farfetched, in my view, to assume that the closure of so many fiefs in the time immediately preceding this decisive event was meant as an integral part of Emperor Wu's overall striving for a more centralized rule ultimately emulating that of the Yellow Thearch (Huangdi). And, what is more, it seems that the historiographer intended to point out this political background

36. For the suggestion that the suspiciously high rate of abolished fiefs in the year 112 , allegedly due to the nobles'negligence in responding to the statute, was probably merely a pretext for Emperor Wu to close the nobilities as a kind of revenge for the refusal of these nobles to support the emperor in his military expeditions, see also Emmerich 1991: 117.

37. Loewe 2004: 294.

38. Cf. Shiji 18.879: 1-6. 
to indicate to his reader the violent and sometimes arbitrary character of this emperor's actions.

\subsection{Assessing Emperor Wu's "Performance" on Mount Tai}

The historiographer's allusion to Gongyang zhuan in chap. 28, the "Monograph on the Feng and Shan Sacrifices," is a peculiar case, since not only the historiographer's personal remark in which the allusion is contained but almost the whole of the chapter content has a doublet in chap. 12, entitled "Basic Annals of (Emperor) Wu the Filial." 39

The main content of this doublet is a description of the steps that Emperor Wu undertook, mainly upon the advice of certain specialists, for performing the sacrifices on Mount Tai as well as a record of the result of these sacrifices. Here is what the Shiji author says in his personal remark which is also part of the doublet and thus found at the end of both chapters:

I accompanied the emperor when he journeyed about to sacrifice to Heaven and Earth, the other deities, and the famous mountains and rivers, and when he went to perform the Feng and Shan. (I) entered the Temple of Long Life and assisted at the sacrifices when the deity spoke, and (I) thus had an opportunity to study and examine the intention ${ }^{40}$ of the men of techniques and the sacrificial officials. After that (I) retired in order to discuss successively how from ancient times services were rendered to the spirits and ghosts, setting forth in doing so both the outside and the inside of these (matters). If there will be superior men in future generations, they may make use of this material for their examination. As for the details of sacrificial plates and utensils, the types of jades and silks offered, or the exact ritual to be followed in presenting them - these may be left to the officials who handle such matters. ${ }^{41}$

But what did the Shiji author mean by mentioning the "outside" and the "inside" of affairs that he intended to set forth in this chapter? It is important to know that

39. Apart from a small introductory section in chap. 12 that offers some biographical data on Han Emperor Wu, the text in chap. 28 (“Feng Shan shu” 封禪書) is an almost 100 percent doublet of chap. 12 ("Xiao Wu benji” 孝武本紀). It has been argued by some that the doublet in chap. 12 was added to the Shiji by a later hand, but as I have tried to show in a previous study, there is good reason to treat both chapters as a "double record" intentionally made by the Shiji author. See Schaab-Hanke 2002b.

40. Where Shiji 28.1404, 4. has yi 意, rendered as “intention," the doublet in Shiji 12.486, 4 has yan 言, “words” instead.

41. Shiji 28.1404, 4-6: 太史公曰: 余從巡祭天地諸神名山川而封禪焉。入壽宮侍祠神 語, 究觀方士祠官之意, 於是退而論次自古以來用事於鬼神者, 具見其表裏。 後有君子, 得以覽焉。至若沮豆珪幣之詳, 獻酬之禮, 則有司存焉。Cf. Shiji 12.486: 4-6. See Watson 1961b: 51f. 
the text begins with a discussion about rulers who from antiquity on either did not proceed to conduct the holy sacrifices on Mount Tai although they would have been worthy to do so, or they proceeded to carry out the sacrifices but were not successful either due to lack of virtue or of merit. From these words it becomes apparent that any ruler who planned to conduct these sacrifices took a certain risk, namely that of possibly not being the right candidate to do so and that of being evaluated accordingly by specialists who knew all the details of the sacrifices.

What follows in the text is a historical survey of rulers who either proceeded with the sacrifices or, for whatever reasons, did not do so. Of these, there are two rulers to whom most space is devoted in the account, namely the First Emperor of Qin and Emperor Wu of the Han. ${ }^{42}$

As for the First Emperor of Qin, it has been pointed out by many that his proceeding to Mount Tai, which is decribed in Shiji chap. 6 as having been motivated primarily by his desire to obtain immortality, was certainly not successful. This is what the record tells us when it says that on his way down from Mount Tai he encountered heavy rain and had to rest under a tree. ${ }^{43}$

As for Emperor Wu then, the direct comparison shows that - at least at first sight - this emperor, in contrast to Qin Shi Huang was seemingly successful. It is even emphasized in the record that there was no rain or thunder when he was on his way to the top of the mountain. He performed the sacrifices and "it seemed" that there were even positive reactions on the part of Heaven.

The question of biao li, or the difference between the outward and the inward behavior is raised precisely in the context of the account of how the emperor was persuaded to take the preparatory measures necessary to conduct the sacrifices on Mount Tai. Very similar to the way the Shiji author informs his readers how the Qin Emperor had been persuaded to put the sacrifices into practice, we learn how Gongsun Qing, a "man of techniques" (fangshi) who was said to have discovered a tripod in Fenyin also claimed to have received an oral prophecy and who told Emperor Wu about the prospect of obtaining immortality after having made a successful sacrifice on top of Mount Tai. Upon this, Emperor Wu is reported by the Shiji author to have exclaimed enthusiastically:

42. While the critical character of the text contained in Shiji 28 (and in Shiji 12) was wholly neglected in the study conducted by Mark Edward Lewis, Hans van Ess emphasizes that chap. 28 was written by Sima Qian with the intention of criticizing Emperor Wu, but he takes the textual parallel in chap. 12 as a later addition by someone else. See Lewis 1999: 50-80; van Ess 2002a; and also 2002b; the latter study is mainly focused on the relationship between Shiji 28 and Hanshu 25A.

43. Shiji 6.242: 9; $c f$. Watson 1993: 46. 
Alas, indeed, if I could only become like the Yellow Thearch, I would regard quitting my wife and children as being no more than casting off one's slippers! ${ }^{44}$

On the one hand this passage clearly illustrates how some of these "men of techniques" such as Gongsun Qing enticed the emperor with the prospect of immortality and thereby managed to manipulate him; and on the other hand the historiographer, through his report of these stories, debunks his own emperor for so easily being manipulated by Gongsun Qing and others like him. ${ }^{45}$

In this context, two more key terms used in the historiographer's personal remark deserve our attention, namely $y i$, "intentions," in contrast to yan, "words." While $y i$ is found in chap. 28 , it is replaced by yan in chap. $12 .{ }^{46} \mathrm{It}$ thus seems as if the annals rnote the official record, whereas in chap. 28 stress is laid upon the critical examination of the circumstance and, above all, of the underlying intent. By pointing out the intentions (yi) beneath Gongsun Qing's words (yan), the historiographer again indicates Emperor Wu's egocentrism and greed. On the other hand, it is perhaps not too farfetched to consider the fact that more than ninety percent of the annals of Emperor Wu are filled with the account of these sacrifices. This should be regarded as quite a distorted and exaggerated treatment of an event, which was certainly important but hardly the only important matter that was worth recording for the long reign of Emperor Wu. Moreover, the inclusion of this event in the annals might even be interpreted as a monument to Wudi's ultimate failure.

In summary, both chap. 28 and its near doublet, chap. 12, appear to be criticism directed at Emperor Wu. They reproach him for arrogance and disrespect in his attitude towards the deities and ghosts, and with having proceeded too quickly and too violently to the performance of the sacrifices, with a primary personal interest in achieving immortality, very much like the "bad model" of the First Emperor of Qin before him. Thus it seems that, in spite of what was formally being recorded as a "success," at closer examination of the underlying intentions, by using the techniques of comparing the "outside" with the "inside" (biao li), in the historiographer's mind Emperor Wu finally turns out not to be the long awaited sage of the Han.

44. Shiji 28.1394; Shiji 12.468: 嗟乎! 吾誠得如黃帝, 吾視去妻子如脫缢耳。See Schaab-Hanke 2002b: 167; 2002a: 305.

45. For an earlier study where I have examined more in detail how Emperor Wu was successively persuaded by what I have called "cosmologists" to proceed to the Feng and Shan Sacrifices, see Schaab-Hanke 2002a.

46. Cf. Shiji 28.1404: 4 (yi) versus Shiji 12.486: 4 (yan), see the translation above. 


\subsection{Storing the work away and devoting it to sages of later ages}

Last but not least, let us take a closer look at the passage contained in chap. 130 of the Shiji, the autobiographical one. ${ }^{47}$ As emphasized in the beginning of this essay, the wording of this last passage comes closest to its prototype in the Gongyang zhuan ${ }^{48}$ Remarkably, the passage is not only part of the "His Lord the Grand Scribe says" section but it is also placed at the end of the rhymed preface related to chap. 130 . Here is the passage in the context of the sentences preceding it:

[This work, which] comprises 130 chapters and consists of 526,500 characters, is the book of His Lord the Grand Scribe. It was compiled in order to repair omissions and amplify the Six Disciplines. It completes the work of one school tradition, by supplementing the various interpretations of the Six Classics and putting into order the miscellaneous sayings of the Hundred Schools. (I) have placed one copy in the Famous Mountain ${ }^{49}$ and another in the capital, so that it may await the sages and superior men of a future generation..$^{50}$

Several aspects of this passage deserve more attention. Apart from being so parallel in its wording to the Gongyang zhuan, it is also conspicuously parallel with regard to its placement in the work. As mentioned above, the passage in the Gongyang zhuan is placed close to the end of the work, and it refers to Confucius who, after the unicorn had been caught, knowing that during his lifetimes no sage ruler was still expected to come, "applied the moral rules of the Spring and Autumn (Annals) to wait for sages of later (generations)."

Similarly, the Shiji passage is placed almost at the end of the Shiji, followed only by one more sentence in which an arc is again traced from the time of the Yellow Thearch (Huangdi) down to the era of Taichu, pointing towards the exact number of chapters, namely altogether 130 , which this work comprises. ${ }^{51}$

47. Shiji 130.3285-3321 (“Taishigong zixu”太史公自序).

48. In his Suoyin commentary, Sima Zhen explicitly points out that it is the Gongyang zhuan to which the historiographer alludes here. See Shiji 130.3321: 9.

49. The "famous mountain" (mingshan 名山) is, according to the explanation given by Sima Zhen, an archive (shufu 書府). See Shiji 130.3321: 6. According to Wang Liqi, this term meant the official court library, as contrasted to the house of the scribe's family in the capital. See Shiji zhuyi, 2791. In the opinion of others, e.g., Zhang Dake, the term might also point toward a private library, such as the scribe's archive. See his Shiji xinzhu, 2175 .

50. Shiji 130.3319: 14-3320, 1: 凡百三十篇, 五十二萬六千五百字, 為太史公書。序 略, 以拾遺補蓺, 成一家之言, 厥協六經異傳, 整齊百家雜語, 藏之名山, 副 在京師, 俟後世聖人君子。第七十。Cf. Watson 1958: 92 .

51. Shiji 130.3321: 11 . 
It thus seems that the implication underlying the allusion to the Gongyang zhuan intended by the historiographer is on the one hand that his work, the Shiji, should somehow be compared or even equated with the Chunqiu, and, what is more, the historiographer himself in consequence seems to take on the role of Confucius. ${ }^{52}$

This is all the more interesting, since in the sentences preceding the passage quoted above, the historiographer diligently enumerates the numbers of the chapters belonging to each category in the Shiji, beginning with the twelve chapters of the section "Annals" (benji), and ending with the seventy chapters subsumed under the category "Biographies" (liezhuan). It almost seems that by enumerating the chapters in this fashion the historiographer wants to safeguard against later additions to, or obliterations from his original work without their being easily detected. ${ }^{53}$ As Jan Assmann has observed, the desire to fix the exact wording of a book for a future generation is typical of cultures which have lost part of their rituals and identity and for whom the compilation of canons thus becomes an essential element to preserve cultural memory. This is what Assmann has called the "canon formula." 54

Last but not least, by pointing out that two copies of the work have been finalized, one to be placed in the "Famous Mountain" (mingshan) and another in the capital - which probably means that one copy should be deposited in the scribe's archive and the other in the house of the Sima clan in Chang'an - the historiographer probably intended to safeguard at least one copy of his work to be preserved for future worthy readers who would draw their conclusions from it. Again it is not farfetched to assume that all this reflects a critical assessment of his present ruler, Emperor Wu.

\subsection{Facets of the historiographer's criticism - a brief synopsis}

It has been argued at the beginning of this essay that each of the five passages of the Shiji text in which the historiographer alludes to the Gongyang zhuan adds one facet to an overall critical assessment of Emperor Wu. ${ }^{55}$ It is now time

52. For a previous essay on Sima Qian as the "second Confucius," see Durrant 1995: 1-28.

53. What the Shiji author is a clear reminder of what we learn in Shiji 85 about the Lüshi chunqiu, with its eight lan, six lun, and twelve $j i$, in all more than 200,000 characters and which its compilator Lü Buwei exhibited at the market gates of Xianyang, announcing that if anyone were able to either add or remove one character of this text he would give him a thousand pieces of gold. See Shiji 85.251: 7-9.

54. See Assmann 1992: 105, where he defines a canon as "die Fortsetzung ritueller Kohärenz im Medium schriftlicher Überlieferung" (extension of ritual coherence by the medium of written transmission).

55. This is, of course, not to deny that there are many other passages in the Shiji that can likewise be adduced to point to the historiographer's overall critical attitude. However, 
to reconsider the facets that we have been able to trace so far and to draw some preliminary conclusions from the previous analysis.

To begin with chap. 15, although there is no explicit criticism in the historiographer's introductory words, there is little doubt that by pointing at Qin, as elsewhere in the Shiji, he implicitly scolded Han. His remarks about the "first signs of prosperity and decay" in his introduction, and even more the "first signs of transgression" he perceives in the early development of the state of Qin on its way to power under a unified rule may certainly also be applied to Emperor $\mathrm{Wu}$ and his rule.

The main lesson to be drawn from Chap. 18 seems to be how violently Emperor Wu abolished almost the half of all fiefs that had been installed either under Gaozu or one of his successors. As has been suggested above, these measures should probably be viewed against the background of Emperor Wu's intended performance of the sacred Feng and Shan Sacrifices on Mount Tai and the installation of the new calendar. It has been suggested that Emperor Wu thus intended to emulate the Yellow Thearch (Huangdi). But of course, less remote though at the same time less successful, the First Emperor, too, is certainly taken here as a model, and this decisive step taken by Emperor Wu, if compared with the time when Liu Bang first established the Han dynasty, reminds one strongly of the passage in Shiji 6, the "Annals of the First August Emperor," where in a dialogue with the Qin Emperor his chancellor Li Si vehemently advises him not to bestow any hereditary fiefs upon officials. ${ }^{56}$

As for the near doublet contained in chap. 28 and 12 of the Shiji, the historical parallel drawn by the historiographer is even more obvious. While the First Emperor's proceeding to Taishan is described in chap. 6 unmistakably as unsuccessful, at first sight Emperor Wu's attempt seems to have been on the whole successful. ${ }^{57}$ However, as we have seen above, the historiographer's subtle rhetoric suggests to an attentive reader that in the context of these sacrifices there was so much wrong or even "fake" that the record at closer reading appears to portray the sacrifices on Mount Tai as unsuccessful. Again, it is the historical example of Qin and its First Emperor which the historiographer uses to criticize Emperor Wu.

the hypothesis proposed here is that the Shiji author intentionally places his allusion to the Gongyang zhuan precisely in these five passages to alert his reader to be more attentive to some information given in the related chapters than he might otherwise have been.

56. See Shiji 6.238: 17-239: 5 (“Qin Shi Huang benji” 秦始皇本紀).

57. Michael Puett has argued that, in the historiographer's mind, only the first step of Emperor Wu's grand project, his sacrificing on Mount Tai, was successful, while the next step, namely that of obtaining immortality, was not. See Puett (2001), esp. p. 202-204. 
Last but not least, the historiographer's reference in chap. 130 to sages and superior men of later generations to whom the work is devoted, in combination with the remark that two copies of the work will be made, one of them to be hidden in the "Famous Mountain," should probably not be interpreted as specific criticism of his emperor. Rather, this final remark seems to be the consequence of all the facets pointed out in the other passages, namely that the lesson to be drawn from all this is not meant to be a pedagogical lesson for a living monarch but rather for one who was not born yet, or for the supporter of such a potential sage ruler in a future age.

In summary, the various facets of the historiographer's criticism identified in the passages discussed above all seem to refer to the preparatory steps Emperor Wu took while he was preparing to conduct the sacrifices on Mount Tai. In fact, some of these measures, as $e . g$. his decision to gradually curb the influence of the nobilities, remind one to some degree of those already taken by his predecessors, beginning with Liu Bang, later Gaozu, who amended his initial project to honor all his loyal followers with a fiefdom or even a kingdom, by proclaiming that henceforth only members of his own clan, Liu, should be made kings. ${ }^{58}$ But whereas Liu Bang's later policy seems to have been a small corrective to his general turn towards a feudal system, in contrast to Qin Shi Huang's wholesale replacement of the earlier fief system in favor of a new centralized system, Emperor $\mathrm{Wu}$, roughly one hundred years after the founding of the Han, almost seems to be following Qin Shi Huang in bringing about a paradigmatic shift of the government system, abolishing most of the fiefs created by the dynasty founder and replacing them by an increasing number of officials serving in a hierarchically structured central government. Viewed in this context, the abolition of fiefs and especially so shortly before the emperor's planned "Grand Inception" could well be interpreted as part of Emperor Wu's new politicoideological agenda in which both the Yellow Thearch (Huangdi), as the ideal ruler of remote antiquity, and the First Emperor, who was less remote in time albeit more an "anti-hero," both played an important part. ${ }^{59}$ Thus, by recording

58. For the idea that an important aspect for Emperor Wu in abolishing the fiefs might have been a lesson drawn from the rebellion of the seven kings in 202, see Emmerich 1991: 116f; also see van Ess (forthcoming).

59. The role of Huangdi as the remote sage whom Emperor Wu seems to have emulated in his efforts to establish his new bureaucratic system has also been emphasized by Michael Puett 2001: 175. He writes that Emperor Wu was claiming that "the norm for succeeding dynasties to follow would not be enfeoffment but imperial centralization, and the organizing sage that such successors would try to emulate would be, Wudi hoped, himself. Empire was thus presented as the new norm, completely in accord with the divine and natural worlds." 
how many of the fiefs established under the dynasty founder had been abolished during the reign of Emperor $\mathrm{Wu}$, the historiographer indirectly points to that decisive step taken by his contemporary ruler.

But whatever the historiographer's general ideological stance towards Emperor Wu's endeavors to achieve a more centralized state system may have been, an important detail concerning the various objects of his criticism that has been mentioned repeatedly is that it was not so much directed against Emperor Wu's actions per se but rather against the way he went about achieving these things. For example, as we saw above, in his account of the dialogue between Gongsun Qing and Emperor Wu the Shiji author emphasizes that the magician finally managed to persuade Emperor Wu to conduct the Feng and Shan Sacrifices with the prospect that by doing so the emperor would gain immortality. By subtly depicting both the underlying intention of the flatterer Gongsun Qing and that of the egocentric and greedy emperor the historiographer uses rhetoric reminiscent of a modern psychologist.

Even more subtle is the historiographer's critical assessment in the abovementioned doublet in chap. 28 and 12. His remark that he "had opportunity to study and examine the intention of the "men of techniques (fangshi) and the sacrificial officials (ciguan), the fact that the word for "intentions" ( $y i$ ) was replaced by that for "words" (yan), in the doublet in chap. 12 suggests that the historiographer intends to reveal to an attentive reader a contradiction between what these men had said (to the emperor, namely that Heaven had reacted positively and Wudi's performance on Mount Tai was thus successful) and their true intention (to flatter the emperor in order to avoid his irritation and to bring benefit primarily for themselves). Of course, by thus analyzing the true motivations behind the deeds of these specialists, the historiographer indirectly also criticized his emperor once again for being so easily misled, thus striking at his vanity and greed.

In all the above mentioned cases it seems that the historiographer gives more weight to attitude or intention than to the deed itself. To give priority to intention rather than to the deed, however, is precisely one of the basic tenets of the Gongyang school. ${ }^{60}$ Perhaps the most prominent example of a historical figure condemned by the author or compiler of the Gongyang zhuan for a murder he clearly did not commit is Zhao Dun, a high minister of Duke Ling of Jin. According to the Gongyang zhuan, Zhao was morally responsible for the murder

60. This is similar with what Jurij Kroll (1976) observed in his study on the impact of the Gongyang zhuan on the Shiji as a literary work and what he calls the Gongyang zhuan's "Concept of Will." 
because he had not only tried to flee from his state after his ruler was killed, but did not even punish the killer after he had returned to his state. ${ }^{61}$

\section{The temporal cesura that turns criticism into "treason"}

So far, this study has been confined to analyzing the various facets of the historiographer's critical assessment of Emperor Wu. But should the criticism passed by the historiographer here simply be understood as a warning, in the hope that the emperor might still change his attitude, or is it rather a judgment passed after a process of evaluation, with the result that a ruler finally turned out to not to be the sage awaited for so long? ${ }^{62}$ It will be argued here that what the historiographer does by addressing later sages and superior men, is the latter, namely the historiographer's final judgment that the emperor was ultimately no sage ruler.

Let us turn once again to our protoype in the Gongyang zhuan. In abstract terms, the appearance of the unicorn in the West in the 14th year of Duke Ai of Lu was for Confucius the signal for a temporal cesura. It seems that until this point in time he was still hoping that a sage ruler would appear during his lifetime. But after he was told that a unicorn had been caught somewhere to the West (of his birthplace Lu), the situation completely changed. The difference was that, for whatever reasons, the master was now certain his fate was that no sage ruler would appear during his lifetime. Therefore he concluded that he should dedicate his great project, a historical record in which he preserved all the right behavior required for the rule of a sage, to superior men of a later age.

Similarly, when the historiographer addresses superior men of later ages, he turns what might be regarded as a simple warning to a ruler for pedagogical purposes into a piece of severe criticism. For this passage informs others that the ruler governing during the time the historiographer was writing in the final analysis turned out to be no sage ruler.

Thus it is precisely the temporal cesura implied here in the Gongyang zhuan which, in its combination with the various facets of the historiographer's critical assessment of his own emperor, turns the rhetorical tool of allusion used by the

61. See Gongyang zhuan, Xuan 6.1; also referred to in Shiji 43.1782: 12; cf. Schaab-Hanke 2010a: $117 \mathrm{f}$.

62. There has been much debate among Shiji specialists as to whether the historiographer's criticism of Emperor Wu should be understood as a warning or rather as a final judgment. See, e.g., Hans van Ess (forthcoming), who argues that Sima Qian's description of Qin Shi Huang's unsuccessful attempt to proceed to Mount Tai was meant merely a warning addressed to Emperor Wu since, in his view, "nothing was obviously proven yet in Emperor Wu's case at the time when Sima Qian was finishing his Shiji.." 
historiographer into a type of dangerous political dynamite. Small wonder that by using such "treasonous" rhetoric, the Shiji author all too easily incurred the risk of being charged with lèse-majesté.

As for the precise point in time which marks the watershed between a still cherished hope and a hope lost, several remarks in the Shiji text suggest that it was not the year in which the sacrifices on Mount Tai took place, namely 110, but rather the year in which the era of Taichu began, namely 104, which had been envisaged by those specialists who were entrusted with calculating the date when the new cycle in the succession of the Yellow Thearch would begin. Since this year was probably also the decisive year in which Emperor Wu, on the basis of these calculations, should have obtained immortality, it was not so difficult for the specialists to determine that at least this second part of the experiment was definitely not successful. ${ }^{63}$

\section{Inconsistencies in the author's attitude towards Emperor Wu}

If one tries to created a picture of how in his account the historiographer assessed Han Wudi, the impression that especially in this regard the historiographer's mirror is, as Durrant has put it in his famous work, "a quite distorted and cloudy one," is indeed quite fitting. ${ }^{64}$ The more one reads this comprehensive work the less one knows for certain whether Emperor Wu is perceived there as the expected sage ruler who has only to be finally approved by Heaven, or whether he is not; the picture is inconsistent; it even seems contradictory at times.

The mirror, however, might become less cloudy if one takes into consideration that we might have to reckon with at least two "mirrors" instead of one. As I have argued elsewhere, there is good reason to assume that there are two significantly different attitudes that can be traced in the Shiji text. ${ }^{65}$ One may be described as quite positive, one that is open-minded to what will happen but at the same time seems to expect that the time when grand events will take place is close;

63. Seen in this light, the doublet in chap. 12 which the Shiji author, as I have argued elsewhere, probably placed there intentionally, seems to show that Emperor $\mathrm{Wu}$ in the end turned out to be not the sage ruler of the Han that many had expected him to be. Perhaps Emperor Wu's failure to obtain immortality was so central to the historiographer that all other events down to the end of his reign may have seemed to him not to be of any more importance.

64. See Durrant 1995: esp. his epilogue, 147. More precisely, Steve Durrant speaks of "Sima Qian's mirror."

65. For an earlier attempt at telling Tan from Qian on the basis of different exegetical attitudes, see Schaab-Hanke 2010a: 127-129. 
one might even characterize this attitude as imbued by an eschatological hope. The other attitude is less positive; it is generally skeptical, at times even cynical, and records things in a much more distant and sober way.

These two attitudes are, as has been argued above, quite irreconcilable. In fact, it almost seems that the historiographer, with quite a different end in mind, is struggling with a story begun by someone else. While he would like to continue the story, he can only do so by reaching a quite different conclusion than the earlier writer intended.

\section{Some final suggestions regarding the "traitor's" identity}

So far, the question of authorship has been avoided in this essay. However, in this last section it will be argued that in the rhetoric of allusion contained in the five passages examined here one can clearly distinguish the voice of one of the two Sima. Those who are accustomed to presuming that Sima Qian was the main author of the Shiji may not find such an assignment noteworthy. However, those who consider the possibility of a dual authorship of the Shiji text may perhaps be interested to apply the implications of the rhetoric of allusion discussed above to the question of how to tell Sima Tan's voice from that of his son Sima Qian.

In what follows it will be argued that the attitude that has been described above as quite positive or even imbued by an eschatological hope is characteristic of Sima Tan, while the less positive, generally skeptical, at times even cynical attitude is the one that characterizes Sima Qian. Since I have discussed elsewhere in some detail the eschatological trait in the overall ideological frame of the Shiji ${ }^{66} \mathrm{I}$ will confine myself to adduce only some examples here which show that the person to whom this attitude may safely be ascribed is Sima Tan.

In chap. 130, the autobiographical and final chapter of the Shiji, there are several passages which may be adduced as examples for the eschatological attitude which can be clearly assigned to Sima Tan. For example, in the famous deathbed scene in which Sima Qian refers to words that he had heard from his father, Sima Tan. Sima Tan laments bitterly over the fact that now, in the very year that Emperor Wu would proceed to the sacrifices on Mount Tai, he would not be able to be in the emperor's entourage. All the more emphatically, he urges his son Qian to continue and finalize what he had intended to write, saying:

66. For more details on the overall ideological frame of the Shiji as a basis trait that may be ascribed to Sima Tan as well as for more on the professional share of the probably three Sima in making preparations for Emperor Wu's grand reforms, see Schaab-Hanke 2002b: 327-334, "The third of them-Sima Xiangru's impact on Emperor Wu's reforms." 
Now the House of Han has arisen and all the world is united under one rule. I have been a Grand Scribe and yet I have failed to set forth a record of the enlightened ruler(s), the worthy nobles, the faithful ministers and the gentlemen who were ready to die for duty. I am fearful that the historical materials will be neglected and lost. You must remember and think of this! ${ }^{67}$

Slightly earlier in the text, Sima Qian reports his father pondering over the "more than four hundred years that have elapsed since the capture of the unicorn," which again suggests that his father was eagerly waiting for the result of the sacrifices that he and his son were preparing for the emperor.

In contrast to his father, Sima Qian witnessed the time after Emperor $\mathrm{Wu}$ conducted the sacred sacrifices on Mount Tai. He also lived long enough to see that his emperor had neither become a sage nor, as the emperor wished, gained immortality. As a result, Sima Qian held a skeptical attitude-perhaps after a time even a cynical one.

There is good reason to assume that all five passages under examination here for their allusion to the Gongyang zhuan have been authored by Sima Qian. That is, he is the one who made use of the rhetorical tool of allusion to make this final critical assessment of his emperor.

The first reason is that, very simply, only Sima Qian but not his father Tan lived long enough to experience the time after Emperor Wu had conducted the sacrifices on Mount Tai. For this reason, both the record of these sacrifices as well as the historiographer's personal remarks which are, as we saw, contained both in chap. 28 and its doublet in chap. 12, were necessarily written by him. The same simple argument concerns the allusion contained at the end of chap. 130, which apart from Sima Tan's words (which are again transmitted to us only thanks to his son's record) must have been written by Sima Qian.

Secondly, but closely related to the first argument, is that precisely because he was the one to experience the time after Emperor Wu's performance on Mount Tai, it was Sima Qian who was faced with the problem to insert the results of what might be called "Emperor Wu's risky experiment somewhere in his father's and his "joint" venture, the Shiji.

My third and last argument in favor of Sima Qian as being the author of our five passages is that there is good reason to assume that he was more familiar with the teachings of the Gongyang school than his father Tan, ${ }^{68}$ especially in

67. Shiji 130.3295, 12f: 今漢興, 海內一統, 明主賢君忠臣死義之士, 余為太史而弗 論載, 廢天下之史文, 余甚懼焉, 汝其念哉！ $C f$. Watson 1958: 49.

68. See, for example, the early identification of “Dong sheng” 董生 with Dong Zhongshu 董仲舒 made by Zhang Shoujie in his Zhengyi commentary, Shiji 1.47. 
the form it was interpreted by the Han scholar Dong Zhongshu (195-115), who had been given an official teaching chair during the reign of Emperor $\mathrm{Wu}$.

Probably the most spectacular passage in the Shiji in which this close familiarity of Sima Qian with the teachings of Dong Zhongshu becomes apparent is the famous conversation with his colleague, the calendar specialist $\mathrm{Hu}$ Sui, where Sima Qian explicitly refers to words that he had heard from the mouth of a certain "Master Dong," who can safely be identified with Dong Zhongshu. ${ }^{69}$

To the suggestive question raised by $\mathrm{Hu}$ Sui, why in Sima Qian's view Confucius decided to “compile the 'Spring and Autumn' (Annals)," Sima Qian responds:

I have heard Master Dong say, "When Confucius was Chief Minister of Justice in Lu, the ways of the Zhou had declined and fallen into disuse. The feudal lords abused him and the high officials obstructed his plans. Confucius realized that his words were not being heeded, nor his doctrines put into practice. So he made a critical judgment of the rights and wrongs of a period of two hundred and forty-two years in order to provide a template of ritually correct behavior for All Under Heaven. He criticized the Son of Heaven, reprimanded the feudal lords, and condemned the high officials in order to make known the business of a true ruler and that was all." 70

Since I have examined the relationship of this passage with the text contained in one chapter of the Chunqiu fanlu, "Luxuriant Dew of the Spring and Autumn (Annals)," a text whose authorship has been ascribed to the Han scholar Dong Zhongshu, in more detail elsewhere, ${ }^{71}$ let me only briefly highlight the main parallels and their context here: That chapter begins with the question about why Confucius compiled the Spring and Autumn Annals. The response is that, on the one hand, it was in order to make a correct record of the Heavenly portenta, of the positions of kings and dukes and of the wishes of the people, and on the other hand, in order to illuminate what brings benefit and what brings loss, in order to help those who have the talent to be worthies to prosper and to wait

69. As for Sima Tan, he certainly knew and may also at times have made use of the Gongyang zhuan, as well as the Guliang zhuan as the third of the three main texts transmitting the ideas laid down in the Chunqiu text, but, as I have argued elsewhere in more detail, Sima Tan was in the first place a cosmologist, and in the second place an exegete who apparently gave preference to the Zuozhuan with its abundant material to make a good historical narrative with political ends. See Schaab-Hanke 2010a: 127-129 (“Sima Tan and Sima Qian-Two Distinct Exegetes?").

70. Shiji 130.3297,8f: 余聞董生曰: 『周道衰廢, 孔子為魯司寇, 諸侯害之, 大夫雍 之。孔子知言之不用, 道之不行也, 是非二百四十二年之中, 以為天下儀表, 貶 天子, 退諸侯, 討大夫, 以達王事而已矣。』Cf. Watson 1958: 50f.

71. See Schaab-Hanke 2010a: 122-126. 
for the sages of later (generations). And finally, that he based his reflections on past events and added to them "the heart of a (true) king." 72

The comparison of that Shiji passage with the above summarized passages from the chapter in the Chunqiu fanlu suggests that several important ideas which Sima Qian elucidates in his dialogue with Hu Sui are taken from the Gongyang zhuan, or at least, from teachings of Dong Zhongshu who for his part interpreted the Gongyang school and applied it on his own times. Firstly, the idea that the reason for Confucius to compile the Chunqiu was indeed that the world was in disorder and decay and that Confucius thereby conceived the work as a "template of ritually correct behavior for All Under Heaven" (tianxia yibiao), to provide a sage ruler who was expected to come sometime in the future. Secondly, the idea that the corrections made by Confucius even included the Son of Heaven, in other words, the one who would make a work which stands in the tradition of the Chunqiu would not only be allowed but even have the duty to criticize even one's ruler. And thirdly, even though there is no parallel to the phrase "to add to (the past events) the heart of a (true) king" in the Shiji text, the author of the Chunqiu fanlu text in this passage quite clearly challenges his reader to examine critically the intention underlying a ruler's deeds. ${ }^{73}$

From all this we may draw two important conclusions. The first is that Sima Qian, who was familiar with the teachings of Dong Zhongshu, may safely be identified as the one who made use of the rhetoric of allusion analysed in this essay. The second conclusion is that the request to record not only the deed itself but also the underlying intent and that the critical examination of this attitude should include even the Son of Heaven is, if not as old as the Gongyang zhuan itself, at least as old as the teachings of Dong Zhongshu interpreting the Gongyang zhuan. Such a request, however, almost inevitably provokes a dilemma, namely precisely the dilemma that becomes evident in the dialogue between Sima Qian and Hu Sui and in which the latter takes the role of an advocatus diaboli who diagnoses the fact that making a historical record following after Confucius is, at the same time, an indirect act of hitting at one's emperor. This dilemma is what Sima Qian must have been keenly aware of when he proceeded to record the events following his father's death, i.e. following

72. Chunqiu fanlu, “Yuxu” 俞序, 6.4/24/17-18: 孔子曰: 『吾因其行事, 而加乎王心 焉, 以為見之空言, 不如行事博深切明。』Cf. the translation by Gentz 2001: $501 \mathrm{ff}$. It should be added that the authenticity of this chapter has been called into question by some, but the fact that the Shiji author quotes them as words he had heard from Dong Zhongshu might even be taken as an argument in favor of its authenticity.

73. There had been much debate on how this difficult passage of the Chunqiu fanlu should be rendered. See, e.g., the proposals by Li 1994: 354, and the discussion in Gentz 2001: 504, n. 18 . 
Emperor Wu's sacrifices on Mount Tai. But as the new "Grand Scribe" and with his father's last words in mind he had no choice but to finish what his father had begun. Thus, rather than blaming him as the "traitor" among the two Sima, we should praise him for fulfilling his duties as an excellent scribe who recorded nothing but the "truth." 74

74. One further important point will, however, be added here, regarding the possibly farreaching political implication of that allusion to the Gongyang zhuan which we by now have been able safely to credit to Sima Qian rather than his father Tan. As has been mentioned in the beginning of this essay, in the context of our Gongyang zhuan passages to which Sima Qian alluded the author of the Gongyang zhuan is reflecting about the possible reasons why Confucius compiled the "Spring and Autumn" Annals, and he asks if "the Master himself took his delight in the way in which Yao recognized Shun." The idea that precisely the theory of voluntary abdication of one ruler in favor of another mentioned here may have been a further central aspect of Dong Zhongshu's teachings has been suggested by Gary Arbuckle. In his essay, he asks if Dong Zhongshu - very much different from the picture that common wisdom generally sketches of him as a kind of master ideologue supporting Emperor Wu in his ambitious plans to become a god-emperor himself - did in reality "perhaps look beyond the contemporary occupants of the throne to those who were destined to succeed them, believing he could predict the course of future history by the employment of some historical scheme?" See Arbuckle 1995: 586. Without providing a response to this he then turns to a Gongyang disciple in the second generation, Sui Hong, who "did indeed believe that the Han mandate had been terminated, a belief that led him to demand that Emperor Zhao (r. 87-74) abdicate in obedience to Heaven." As for Sima Qian, there is, in my view, no evidence for any concrete ideas on his part that would suggest that Emperor Wu, too, should abdicate in favour of another ruler. However, it is important to note that when the later Zhaodi was still a child and Huo Guang who had been appointed by Emperor Wu to the position of a regent there was, as Arbuckle: 587, has also mentioned, "a good deal of evidence that a pedigree was being forged for him that 'proved' his descent from the Yellow Lord, and which would have justified his claiming the imperial throne as successor to the Han." It is precisely this pedigree which has been added later by someone, probably Chu Shaosun, to chap. 20 of the Shiji. As I have argued in a previous study, Chu might have intended to alert the reader that Sima Qian's son in law, Yang Chang, cherished the hope that Huo Guang would become Wudi's successor. For the group around Huo Guang, see Schaab-Hanke 2003/2004: 227f, 239f. It thus seems that while there were no imminent political conclusions of the rhetorical tool of allusion used by Sima Qian, in the long run the allusion seems to have worked - at least in the heads of some-a bit like a ticking time bomb. 


\section{BIBLIOGRAPHY}

ArbuCKLE, Gary (1995). “Inevitable Treason: Dong Zhongshu's Theory of Historical Cycles and Early Attempts to Invalidate the Han Mandate." JAOS, no. 115.4: 585597.

Assmann, Jan (1992). Das kulturelle Gedächtnis: Schrift, Erinnerung und politische Identität in frühen Hochkulturen. München, C. H. Beck.

Chavannes, Édouard (1898). Les Mémoires historiques de Se-ma Ts'ien. Tome troisième. Paris, Lerous.

CHEN, Tongsheng 陳桐生 (1995). Shiji yu jin gu wen jingxue 《史記》與今古文經學. Shantou, Shaanxi renmin jiaoyu.

Chunqiu, fanlu 春秋繁露 (1994). By Dong Zhongshu 董仲舒. ICS edition. Chunqiu fanlu zhuzi suoyin 春秋繁露逐字索引 = A Concordance to the Chunqiu fanlu, ed. Chinese University of Hong Kong. Hongkong, Shangwu.

Dubs, Homer H. (1944). "The Eighth Month Fermented Wine Offering." In his The History of the Former Han Dynasty, vol. II. Baltimore, Waverly: 126-128.

Durrant, Stephen W. (1992). "Ssu-ma Ch'ien's Conception of Tso chuan." JAOS, no. 112.2: 295-301.

Durrant, Stephen W. (1994). "Ssu-ma Ch'ien's Portrayal of the First Ch'in Emperor." In Brandauer, Frederick P. and Huang Chun-chieh (eds), Imperial Rulership and Cultural Change in Traditional China. Seattle and London: University of Washington: 28-50.

Durrant, Stephen W. (1995). The Cloudy Mirror: Tension and Conflict in the Writings of Sima Qian. SUNY series in Chinese philosophy and culture. Albany, State University of New York.

EMmERICH, Reinhard (1991). "Chu and Changsha am Ende der Qin-Zeit und zu Beginn der Han-Zeit," Oriens Extremus, no. 34: 85-137.

Ess, Hans van (2002a). "Implizite historische Urteile in den Opfertraktaten von Ssu-ma Ch'ien and Pan Ku." Oriens Extremus, no. 43: 40-50.

Ess, Hans van (2002b). "Der Sinn des Opfertraktates feng-shan shu des Ssu-ma Ch'ien." Archiv Orientàlnì, no. 70: 125-132.

Ess, Hans van (forthcoming). "Emperor Wu of the Han and the First August Emperor of Qin in Sima Qian's Shiji." In Pines, Yuri, Shelach, Gideon, Falkenhausen, Lothar von and Yates, Robin D.S. (eds), The Birth of Empire: The State of Qin Revisited. Berkeley, University of California.

Gentz, Joachim (2001). Das Gongyang zhuan: Auslegung und Kanonisierung der Frühlings-und Herbstannalen (Chunqiu). Opera Sinologica, no. 12. Wiesbaden, Harrassowitz.

Gongyang, zhuan 公羊傳 (1995). ICS edition. Gongyang zhuan zhuzi suoyin 公羊傳 逐字索引 = The Concordance to the Gongyangzhuan, ed. Chinese University of Hong Kong. Hongkong, Shangwu.

Guliang, zhuan 穀梁傳 (1995). ICS edition. Guliang zhuan zhuzi suoyin 穀梁傳逐字 索引 = The Concordance to the Guliangzhuan, ed. Chinese University of Hong Kong. Hongkong, Shangwu. 
HARDY, Grant R. (1993). "The Interpretive Function of Shih chi 14, 'The Table by Years of the Twelve Feudal Lords'.” JAOS, no. 113.1: 14-24.

HulSEwÉ, A.F.P. (1955). Remnants of Han Law, vol. I. Leiden, Brill.

Hulsewé, A.F.P. (1989). "Founding Fathers and Yet Forgotten Men: A Closer Look at the Tables of the Nobility in the Shih Chi and the Han shu." T'oung Pao, no. 75: 43-126.

Kroll, Jurij L. (1976). "Ssuma-Ch'ien's Literary Theory and Literary Practice," Altorientalische Forschungen IV: 313-325.

LEwIs, Mark Edward (1999). "The Feng and Shan Sacrifices of Emperor Wu of the Han.” In McDermott Joseph P. (ed.), State and Court Ritual in China. Cambridge, Cambridge University Press: 50-80.

LI, Wai-yee (1994). "The Idea of Authority in the Shih Chi (Records of the Historian)." HJAS, no. 54.2: 345-405.

Loewe, Michael (2000). A Biographical Dictionary of the Qin, Former Han and Xin Periods (221BC-AD 249). Handbuch der Orientalistik, IV, 16. Leiden, Brill.

Loewe, Michael (2004). The Men Who Governed Han China. Companion to A Biographical Dictionary of the Qin, Former Han and Xin Periods. Leiden: Brill.

Nylan, Michael (1998-1999). "Sima Qian: A True Historian?” Early China, no. 23-24: 203-246.

PInEs, Yuri (2005/6). "Biases and Their Sources: Qin History in the Shiji." Oriens Extremus, no. 45: 10-34.

Puetr, Michael (2001). The Ambivalence of Creation: Debates Concerning Innovation and Artifice in Early China. Stanford, Stanford University.

RuAN, Zhisheng 阮芝生 (1996). “San Sima yu Han Wudi fengshan”三司馬與漢武帝 封禪, Guo li Taiwan daxue lishi xuexi xuebao, no. 20: 307-340.

SchaAb-Hanke, Dorothee (2002a). "The Power of an Alleged Tradition: A Prophetic Message Flattering Han Emperor Wu and Its Relation to the Sima Clan" [first published in BMFEA, no. 74 (2002): 243-290], cited after the rev. version in Schaab-Hanke, Dorothee (2010): 293-346.

SchaAB-Hanke, Dorothee (2002b). "Der Herrscher und sein Richter: Zur Bedeutung von biao 表 und $l i$ 裏 in Kapitel 28 des Shiji" [first published in Oriens Extremus, no. 43: 116-144], cited after the rev. version in: Schaab-Hanke, Dorothee (2010): 141-178.

SchaAb-Hanke, Dorothee (2003/2004). "Did Chu Shaosun Contribute to a Tradition of the Grand Scribe?" [first published in Oriens Extremus, no. 43: 11-26], cited after the rev. version in Schaab-Hanke, Dorothee (2010): 225-243.

SchaAb-Hanke, Dorothee (2010a). "The Junzi in the Shiji and the Quest for Moral Authorities" In Schaab-Hanke, Dorothee (2010): 105-138.

SchaAB-HANKe, Dorothee (2010b). Der Geschichtsschreiber als Exeget: Facetten der frühen chinesischen Historiographie. Deutsche Ostasienstudien, 10. Gossenberg, Ostasien Verlag.

Shiji 史記. By Sima Tan 司馬談 (?-110) and Sima Qian 司馬遷 (ca 145-ca 86). Annotated by Zhang Shoujie 張守節, Sima Zhen 司馬貞, and Pei Yin 裴駰. Beijing, Zhonghua, 1959. 
Watson, Burton (1958). Ssu-ma Ch'ien: Grand Historian of China. New York, Columbia University.

W ATson, Burton (1961a). Records of the Grand Historian: Han Dynasty I. New York, Columbia University.

Watson, Burton (1961b). Records of the Grand Historian: Han Dynasty II. New York, Columbia University.

Watson, Burton (1993). Records of the Grand Historian: Qin. New York, Columbia University.

Zhang, Dake (2000). Shiji xinzhu. Beijing, Huawen.

Zuozhuan 左傳. ICS edition (1995). Chunqiu Zuozhuan zhuzi suoyin 春秋左傳逐字索 引 = The Concordance to the Chunqiu Zuozhuan, ed. Chinese University of Hong Kong. Hongkong, Shangwu.

\section{GLOSSARY}

benji 本紀

biao li 表裏

Chunqiu 春秋

Chunqiu fanlu 春秋繁露

ciguan 祠官

Dong Zhongshu 董仲舒

fangshi 方士

feng shan 封禪

Gongyang zhuan 公羊傳

Guliang zhuan 穀梁傳

hou 候

Huangdi 黃帝

junzi yue 君子曰

liezhuan 列傳

mingshan 名山

Qin Shi Huang 秦始皇

Shiji 史記

shufu 書府

Sima Qian 司馬遷

Sima Tan 司馬談

Taichu 太初

taishi gong yue 太史公曰

taishi ling 太史令

tianxia yibiao 天下儀表

Wu di 武帝

xing shuai zhi duan 興衰之端

yan 言

yi 意

Yuanfeng 元封

zhi Chunqiu 制春秋

zhoujin lü 酎金律 